\title{
Effect of selected flavones on cancer and endothelial cells
}

\author{
Martina Pilátová ${ }^{1}$, Viktória Stupáková1 ${ }^{1}$ Lenka Varinská ${ }^{1}$, Marek Šarišský1, Ladislav Mirossay ${ }^{1}$, \\ Andrej Miroššay ${ }^{1}$, Peter Gál ${ }^{1}$, Vladimír Kraus ${ }^{2}$, Katarína Dianišková ${ }^{2}$ and Ján Mojžišs ${ }^{1}$ \\ ${ }^{1}$ Department of Pharmacology, Faculty of Medicine, P. J. Šafárik University, Košice, Slovakia \\ ${ }^{2} 1$ st Department of Gynaecology and Obstetrics, Faculty of Medicine, P. J. Šafárik University, Košice, Slovakia
}

\begin{abstract}
In our study we used quercetin (3,3', $4^{\prime}, 5,7$-pentahydroxyflavone) as the reference standard to compare antiproliferative and antiangiogenic effects of chrysin (5,7-dihydroxyflavone) and 3-hydroxyflavone.

Our data indicates that chrysin and 3-hydroxyflavone showed significantly higher cytotoxic effect than reference standard quercetin. These tested agents significantly decreased cell survival with the efficacy of $65-85 \%$ at the concentration $100 \mu \mathrm{mol} / \mathrm{l}$ for HUVEC, lung carcinoma and leukemic cells being the most sensitive. Cell cycle analysis indicates that quercetin and 3-hydroxyflavone might affect the cell cycle of Jurkat cells by a similar or the same mechanism of action which lead to $\mathrm{G}_{2} / \mathrm{M}$ arrest as well as to an increase in sub- $G_{0} / G_{1}$ fraction. Treatment of Jurkat cells with chrysin resulted only increase in the fraction of cells with sub- $G_{0} / G_{1}$ DNA content, which is considered to be a marker of apoptotic cell death. Apoptosis was confirmed by DNA fragmentation and by staining with annexin $\mathrm{V}$.

All three tested flavones inhibited endothelial cell migration after $24 \mathrm{~h}$ of incubation at a concentration $100 \mu \mathrm{mol} / \mathrm{l}$. At a lower concentration $(10 \mu \mathrm{mol} / \mathrm{l})$ only quercetin significantly inhibited migration of endothelial cells. Furthermore, in our experiments decreased secretion of matrix metalloproteinases (MMP-2 and MMP-9) was observed after a $72 \mathrm{~h}$ treatment with quercetin. No decrease in secretion of MMP-2 and MMP-9 was seen after chrysin and 3-hydroxyflavone treatment. On the other hand, our results showed that none of three flavonoids blocked microcapillary tube formation.

Further studies are necessary to investigate the mechanism of action and to find out the relationship between the structure, character and position of substituents of natural substances and their biological activities.
\end{abstract}

Key words: Chrysin - 3-Hydroxyflavone - Quercetin - Antiproliferative - Antiangiogenic

\begin{abstract}
Abbreviations: bFGF, basic fibroblast growth factor; EGCG, epigallocatechin gallate; HUVECs, human umbilical vein endothelial cells; MMP, matrix metalloproteinase; MTT, 3-(dimethylthiazol2-yl)-2,5-diphenyltetrazolium bromide; PBS, phosphate buffered saline; PCNA, proliferating cell nuclear antigen; PI, propidium iodide; SDS, sodium dodecyl sulfate; VEGF, vascular endothelial growth factor.
\end{abstract}

\section{Introduction}

Consumption of a plant-based diet can prevent the development and progression of chronic diseases, including malignant tumors and cardiovascular diseases (Mojzisova

Correspondence to: Jan Mojzis, Department of Pharmacology, Faculty of Medicine, P. J. Safarik University, Trieda SNP 1, 04011 Kosice, Slovakia

E-mail: jan.mojzis@upjs.sk and Kuchta 2001; Mojzisova and Mojzis 2008). Various hypotheses have been suggested to explain these beneficial effects of increased consumption of vegetables and fruits. Great interest is currently being paid to flavonoids, one of the major classes of natural products with widespread distribution in fruits, vegetables, spices, tea and soy-based foodstuff, for their interesting pharmacological activities (Pouget et al. 2001).

Flavonoids have a common C6-C3-C6 structure consisting of two aromatic rings linked through an oxygenated heterocycle 
(which is fused to one of these aromatic rings). Approximately, 8000 flavonoids have been characterized and the major classes are flavones (apigenin, luteolin), flavonols (quercetin, kaempferol), flavanones (hesperetin, naringenin), flavanols (epigallocatechin, EGCG), anthocyanins (cyanidnin, delphinidin) and isoflavones (genistein, daidzein) (Duthie et al. 2003).

Flavonoids display a remarkable spectrum of biochemical activities including those that might be able to influence processes that are dysregulated during cancer development. These include e.g. antioxidant activities (Sivonova et al. 2006), the scavenging effect on activated carcinogens and mutagens (Delgado et al. 2008), the action on proteins that control cell cycle progression ( $\mathrm{Li}$ et al. 2005) and gene expression (Hakimuddin et al. 2008). Moreover, it was documented that flavonoids possess also antiangiogenic properties (Mojzis et al. 2008).

One of the major representatives of flavonoids widely studied for antiproliferative and tumor reducing activity is quercetin (Alia et al. 2006). A number of its actions make it a potential anticancer agent including cell cycle regulation, interaction with type II estrogen binding sites and tyrosine kinase inhibition (Lamson and Brignall 2000). Quercetin has also been shown to increase the therapeutic efficiacy of cisplatin in both in vitro and in vivo conditions (Lamson and Brignall 2000; Chan et al. 2003; Cipák et al. 2003). Moreover, quercetin also caused an enhancement of radiation toxicity in rat hepatoma cells (van Rijn and van den Berg 1997). Nowadays, quercetin is available as a free-sale nutrition suplement and one of its indications is cancer prevention.

However, flavonoids are still sufficiently flexible to permit a wide variety of conformation providing with new opportunities for investigation, because their biological effects are affected by structure, character and position of their substituents. It was suggested that the presence of a $\mathrm{C} 2-\mathrm{C} 3$ double bond and three adjacent hydroxyl groups in the flavonoid confers greater antiproliferative activity to the flavonoid (Martínez et al. 2003).

In our study we used quercetin $\left(3,3^{\prime}, 4^{\prime}, 5,7\right.$-pentahydroxyflavone) as the reference standard to compare antiproliferative effects of chrysin (5,7-dihydroxyflavone) and 3-hydroxyflavone. Moreover, because it is evident that progressive tumor growth is dependent on angiogenesis, we also studied antiangiogenic effect of above mentioned flavonoids.

\section{Materials and Methods}

\section{Reagents and drugs}

MTT (3-(dimethylthiazol-2-yl)-2,5-diphenyltetrazolium bromide) was from Sigma-Aldrich Chemie (Steinheim, Germany). Tested chemicals: quercetin, chrysin and 3-hydroxyflavone were purchased from Sigma (Germany) (chemical structures see in Fig. 1). Cycle TEST ${ }^{\mathrm{TM}}$ PLUS DNA Reagent Kit, annexin V-FITC and propidium iodide were purchased from Becton Dickinson (USA).

\section{Cell culture}

A-549 (lung carcinoma), HepG2 (hepatocellular carcinoma), MCF-7 (mammary gland adenocarcinoma, estrogen receptor expressed), Jurkat cells (acute T-lymphoblastic leukemia, Bcl-2 overexpressed), CEM (acute T-lymphoblastic leukemia), U-87 MG (glioblastoma, astrocytoma, wild type p53 expressed), U-373 MG (glioblastoma, astrocytoma, mutant type p53 expressed) were maintained in RPMI 1640 medium with Glutamax-I supplemented or D-MEM medium with Glutamax-I and glucose supplemented in with $10 \%$ foetal calf serum, penicillin $(100 \mathrm{IU} / \mathrm{ml})$ and streptomycin $(100 \mu \mathrm{g} / \mathrm{ml})$ (all from Invitrogen, $\mathrm{UK}$ ), in the atmosphere $5 \% \mathrm{CO}_{2}$ in humidified air at $37^{\circ} \mathrm{C}$. Cell viability, estimated by trypan blue exclusion, was greater than $95 \%$ before each experiment.

\section{Assessment of cytotoxicity by MTT assay}

The cytotoxic effect of the tested compounds was studied by using colorimetric microculture assay with the MTT end-point. The amount of MTT reduced to formazan was<smiles>O=c1c(O)c(-c2ccc(O)c(O)c2)oc2cc(O)cc(O)c12</smiles>

Quercetin<smiles>O=c1cc(-c2ccccc2)oc2cc(O)cc(O)c12</smiles>

Chrysin<smiles>O=c1c(O)c(-c2ccccc2)oc2ccccc12</smiles>

3-Hydroxyflavone

Figure 1. Chemical structure of flavonoids. Quercetin (3,3',4',5,7-pentahydroxyflavone), chrysin (5,7-dihydroxyflavone) and 3-hydroxyflavone. 
proportional to the number of viable cells (Mosmann 1983). Briefly, $5 \times 10^{3}$ cells were plated per well in 96 -well polystyrene microplates (Sarstedt, Germany) in the culture medium containing the tested chemicals at final concentrations $10^{-4}-10^{-6} \mathrm{~mol} / \mathrm{l}$. After $72 \mathrm{~h}, 10 \mu \mathrm{l}$ of MTT $(5 \mathrm{mg} / \mathrm{ml})$ were added in each well. After an additional $4 \mathrm{~h}$, during which insoluble formazan was produced, $100 \mu \mathrm{l}$ of $10 \%$ sodium dodecylsulphate were added in each well and another $12 \mathrm{~h}$ were allowed for the formazan to be dissolved. The absorbance was measured at $540 \mathrm{~nm}$ using the automated MRX microplate reader (Dynatech laboratories UK). Absorbance of control wells was taken as $100 \%$, and the results were expressed as a percent of control.

\section{Cell cycle analysis}

Cell cycle distribution in cells treated with the tested agents was analyzed by propidium iodide (PI) DNA staining using a Cycle TEST ${ }^{\mathrm{TM}}$ PLUS DNA Reagent Kit (Becton Dickinson, USA). Briefly, $5 \times 10^{5}$ Jurkat cells were treated with flavones at concentration $100 \mu \mathrm{mol} / \mathrm{l}$ for $72 \mathrm{~h}$. After treatment, cells were harvested and washed twice in PBS. Then, they were processed and stained according to the manufacturer's instructions. After staining, samples were immediately acquired on a FACS Vantage SE flow cytometer using CellQuest software (Becton Dickinson, USA). Fifthy thousand cells were required per analysis. PI fluorescence was detected in the pulseprocessed FL3 channel (630/22 nm band pass filter). Results were analyzed using Win MDI software and expressed in the form of histograms (Fig. 2). Percentages of cells corresponding to $G_{0} / G_{1}, S$ and $G_{2} / M$ phases of the cell cycle were calculated. Cells with hypodiploid DNA (content less than that $G_{0} / G_{1}$-phase cells) were considered to be apoptotic (sub- $\mathrm{G}_{0} / \mathrm{G}_{1}$ ). Performance of the instrument and sensitivity of measurement were checked prior to acquisition by using a DNA QC Particle Kit (Becton Dickinson, USA).

\section{Annexin V/PI staining}

The assay was performed as described previously (Kravtsov et al. 1998). Briefly, $5 \times 10^{5}$ Jurkat cells after drug exposure ( $100 \mu \mathrm{mol} / \mathrm{l}$ for $72 \mathrm{~h}$ ) were washed twice in PBS and resuspended in $100 \mu \mathrm{l}$ of binding buffer (Becton Dickinson, USA). The cells were subsequently stained with annexin V-FITC (An) and PI (Becton Dickinson, USA) according to the manufacturer's instructions. After staining, the cells were resuspended in $400 \mu \mathrm{l}$ of binding buffer and $10^{4}$ events were acquired immediately using the FACS Vantage SE flow cytometer (Becton Dickinson, USA). Annexin V-FITC and PI fluorescences were detected in FL1 (530/30 nm band pass filter) and FL3 (630/22 nm band pass filter) channels. Samples were acquired and analyzed using the CellQuest software (Becton Dickinson, USA). The results are represented in the form of dot plots divided into 4 quadrants: the lower left quadrant of the dot plots shows viable, $\mathrm{An}^{-} /$ $\mathrm{PI}^{-}$cells; the lower right quadrant shows early apoptotic cells with preserved plasma membrane integrity $\left(\mathrm{An}^{+} / \mathrm{PI}^{-}\right)$; the upper right quadrant shows late apoptotic/necrotic cells which have lost their plasma membrane integrity and have become $\mathrm{An}^{+} / \mathrm{PI}^{+}$.

\section{DNA fragmentation assay}

Treated (for 24, 48 and $72 \mathrm{~h})$ and untreated cells $\left(1 \times 10^{-6}\right)$ were washed twice with PBS calcium and magnesium free. Lysation of cells was provided in a lysis buffer containing 10 $\mathrm{mmol} / \mathrm{l} \mathrm{TRIS}, 10 \mathrm{mmol} / \mathrm{l}$ EDTA, $0.5 \%$ Triton X-100. Proteinase $\mathrm{K}(1 \mathrm{mg} / \mathrm{ml})$ was added and cells were incubated at $37^{\circ} \mathrm{C}$ for $1 \mathrm{~h}$. Then they were heated at $70^{\circ} \mathrm{C}$ for 10 minutes and after adding RNAase $(200 \mu \mathrm{g} / \mathrm{ml})$ the cells were incubated at $37^{\circ} \mathrm{C}$ for $1 \mathrm{~h}$, again. Samples were transfered to $2 \%$ agarose gel and run with $40 \mathrm{~V}$ for $3 \mathrm{~h}$. DNA fragments were visualized by a UV illuminator.

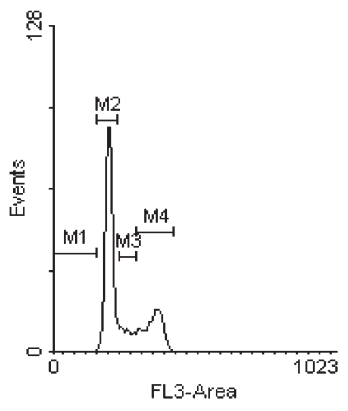

control

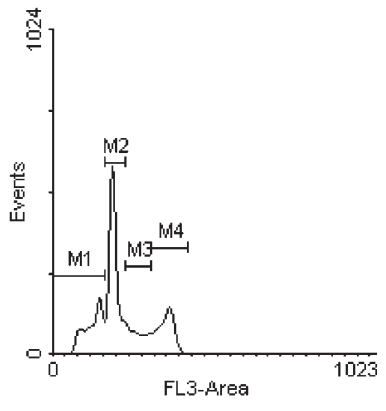

Q

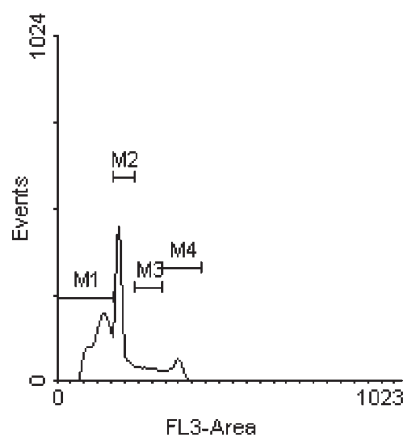

$\mathrm{CH}$

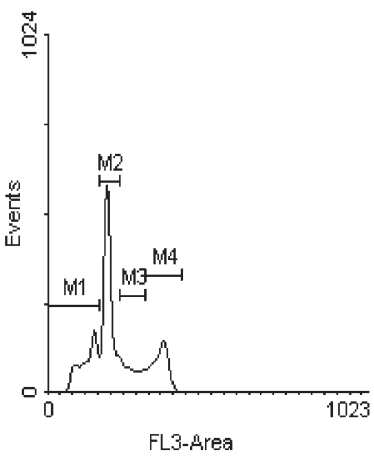

3-HF

Figure 2. Effect of quercetin $(\mathrm{Q})$, chrysin $(\mathrm{CH})$ and 3-hydroxyflavone (3-HF) on the cell cycle progression in Jurkat cells. Jurkat cells were treated with vechicle (control) or various flavonoids at concentration of $100 \mu \mathrm{mol} / \mathrm{l}$ for $72 \mathrm{~h}$. The data are representative of three independent experiments. $M_{1}$, sub- $G_{0} / G_{1} ; M_{2}, G_{0} / G_{1} ; M_{3}, S ; M_{4}, G_{2} / M_{2}$. 


\section{Primary endothelial cells isolation and culture}

Human umbilical vein endothelial cells (HUVECs) were isolated from freshly collected human umbilical cords by collagenase digestion of the interior of the umbilical vein with $0.1 \%$ collagenase II (Gibco, USA) solution by modified method described by Jaffe et al. (1973) and Marin et al. (2001). Cells were grown in the atmosphere $5 \% \mathrm{CO}_{2}$ in humidified air at $37^{\circ} \mathrm{C}$ in Medium 199 supplemented with $20 \%$ heatinactivated fetal bovine serum, $100 \mu \mathrm{g} / \mathrm{ml}$ streptomycin, 100 $\mathrm{IU} / \mathrm{ml}$ penicillin (all from Gibco, USA). They were confirmed as endothelial cells by their "cobblestone" morphology and positive expression of CD31 markers, universal markers for endothelium, using monoclonal antibody to the human CD31 antigen (Caltag Laboratories, Burlingame, CA, USA) by flow cytometry (FACS Vantage SE, Becton Dickinson, USA).

\section{Endothelial cells migration assay}

The migratory activity of HUVEC was assessed using a wounded migration assay (Martínez-Poveda et al. 2005). Confluent monolayers in 24-well plates were wounded with pipets tips giving rise to acellular line per well. After PBS washing, the cells were supplied with a culture medium without (controls) or with flavones. The wounded areas were photographed. The plates were observed under microscope at different times during the incubation and the same areas were photographed as in zero time.

\section{In vitro angiogenesis assay}

Capillary tube formation of endothelial cells was performed by using a Fibrin gel in vitro angiogenesis assay kit (Chemicon, USA) according to the manufacturer's instructions. Briefly, to examine the effect of compounds studied in this process, HUVEC (5000 cells/well) in $100 \mu$ l Endomed (Biochrom AG, Germany) supplemented by a growth factor VEGF were simultaneously seeded with flavonoids $\left(10^{-6} \mathrm{~mol} / \mathrm{l}\right)$ in fibrincoated 96-well culture plates. Tube formation was observed periodically over time under a phase contrast microscope.

\section{MMP gelatinase activity}

Proteases that have the ability to renature after removal of SDS and to exert proteolytic activity on a co-polymerized substrate can be analyzed with this method. MMP-2 $(72 \mathrm{kD})$ and MMP-9 $(92 \mathrm{kD})$ can be detected on gelatin zymograms. Based on the molecular weights, these bands reflect inactive and active MMP-2 and inactive and active MMP-9. Matrix metalloproteinases released into conditioned media were determined by gelatinase zymography according to the method of Newcomb et al. (2005). Cells were grown to confluency in 6-well chamber plates and incubated for $24 \mathrm{~h}$ with tested flavones at concentrations $10^{-4}-10^{-8} \mathrm{~mol} / \mathrm{l}$. Proteins were separated electrophoretically at $4^{\circ} \mathrm{C}$ in an $8 \%$ SDS-polyacrylamide gel containing $0.1 \%$ type B gelatin (Sigma Chemical Co., St. Louis, MO, USA). The gel was rinsed three times for $20 \mathrm{~min}$ in $2.5 \%$ Triton $\mathrm{X}-100$, followed by digestion (50 $\mathrm{mmol} / \mathrm{l}$ Tris- $\mathrm{HCl}$ ( $\mathrm{pH} 7.5$ ), $200 \mathrm{mmol} / \mathrm{l} \mathrm{NaCl}, 5 \mathrm{mmol} / \mathrm{l} \mathrm{CaCl}_{2}$, and $0.02 \% \mathrm{NaN}_{3}$ ) at $37^{\circ} \mathrm{C}$ for $36 \mathrm{~h}$. The gel then was stained with $0.05 \%$ Coomassie Blue in methanol, acetic acid, and $\mathrm{H}_{2} \mathrm{O}$ $(3: 1: 6)$ at room temperature for $1 \mathrm{~h}$ and destained in the same solution without Coomassie Blue three times for $15 \mathrm{~min}$. A decrease in staining intensity is a reflection of a decreased gelatinolytic activity of MMP-2 and MMP-9.

\section{Statistical analysis}

For all experiments, mean values and standard deviations (from 5 experiments) were calculated using the ArcusQuickstat software package. To evaluate the statistical significance observed between groups, a Student's $t$-test was employed. The statistical significance was considered to be present if $p<0.01$.

\section{Results}

Cytotoxic assay

Survival of different cancer and endothelial cells expossed to $72 \mathrm{~h}$ incubation with tested flavones at a concentration 100 $\mu \mathrm{mol} / \mathrm{l}$ is shown in Table 1 . Our data indicates that chrysin

Table 1. Effects of flavones on viability of cancer (A-549, HepG2, MCF-7, Jurkat, CEM, U-87 MG, U-373 MG) and endothelial (HUVEC) cells after $72 \mathrm{~h}$ incubation at flavones concentration $100 \mu \mathrm{mol} / \mathrm{l}$ detected by MTT test (in \%) and $\mathrm{IC}_{50}$ (in $\mu \mathrm{mol} / \mathrm{l}$ )

\begin{tabular}{llccc}
\hline & & Quercetin & Chrysin & 3-Hydroxyflavone \\
\hline \multirow{2}{*}{ A-549 } & Viability & 55.7 & 16.7 & 19.8 \\
& IC $_{50}$ & $>100$ & 79,8 & 81 \\
\cline { 2 - 5 } HepG2 & Viability & 90.4 & 35.3 & 35.4 \\
& IC $_{50}$ & $>100$ & 88.5 & 88.5 \\
\cline { 2 - 5 } MCF-7 & Viability & 40.6 & 23.9 & 27.9 \\
& IC $_{50}$ & 91.7 & 82.5 & 84.3 \\
\cline { 2 - 5 } Jurkat & Viability & 42.9 & 13.7 & 20.8 \\
& IC $_{50}$ & 93.1 & 78.7 & 81.3 \\
\cline { 2 - 5 } CEM & Viability & 25.9 & 16.4 & 25.7 \\
& IC $_{50}$ & 79.2 & 79.8 & 76.4 \\
\cline { 2 - 5 } U-87MG MG & Viability & 71.1 & 60.2 & 58.5 \\
& IC $_{50}$ & $>100$ & $>100$ & $>100$ \\
\cline { 2 - 5 } U-373MMG & Viability & 85.5 & 30.2 & 63.4 \\
& IC $_{50}$ & $>100$ & 85,7 & $>100$ \\
\cline { 2 - 4 } HUVEC & Viability & 98.8 & 23.4 & 20.1 \\
& IC $_{50}$ & $>100$ & 82.5 & 81.3 \\
\hline
\end{tabular}


Table 2. Flow cytometric analysis of cell cycle distribution in Jurkat cells treated with flavonoids (in \%)

\begin{tabular}{lcccc}
\hline & sub- $\mathrm{G}_{0} / \mathrm{G}_{1}$ & $\mathrm{G}_{0} / \mathrm{G}_{1}$ & $\mathrm{~S}$ & $\mathrm{G}_{2} / \mathrm{M}$ \\
\hline Control & $2.17 \pm 0.31$ & $73.64 \pm 5.33$ & $11.63 \pm 2.18$ & $12.77 \pm 2.22$ \\
Quercetin & $24.27 \pm 3.28^{\mathrm{a}}$ & $39.94 \pm 3.98^{\mathrm{a}}$ & $14.94 \pm 1.23$ & $21.18 \pm 1.17^{\mathrm{a}}$ \\
Chrysin & $44.35 \pm 2.8^{\mathrm{a}}$ & $35.38 \pm 2.84^{\mathrm{a}}$ & $10.9 \pm 1.58$ & $9.94 \pm 1.19$ \\
3-Hydroxyflavone & $20.35 \pm 1.13^{\mathrm{a}}$ & $41.8 \pm 4.22^{\mathrm{a}}$ & $15.64 \pm 2.33$ & $22.21 \pm 2.06^{\mathrm{a}}$ \\
\hline
\end{tabular}

Cells were exposed to flavonoids $(100 \mu \mathrm{mol} / \mathrm{l})$ for 72 hours. ${ }^{\mathrm{a}} p<0.001 \mathrm{vs}$. control.

and 3-hydroxyflavone showed significantly higher cytotoxic effect than reference standard quercetin. These tested agents significantly decreased cell survival with the efficacy of $65-85 \%$ at the highest tested concentration $(100 \mu \mathrm{mol} / \mathrm{l})$ for HUVEC, lung carcinoma and leukemic cells being the most sensitive. Inhibition of cell proliferation by examined flavones was weaker in glioma cell lines. Nearly no effect on HUVEC and hepatocellular carcinoma cell line was noted after treatment with quercetin at the same concentration. In the rest of the exerted cancer cell lines quercetin treatment caused a $15-75 \%$ reduction in cell survival at this concentration. At lower concentrations (10 and $1 \mu \mathrm{mol} / \mathrm{l})$, no inhibition was observed.

\section{Cell cycle analysis}

Cell cycle analysis of Jurkat cells exposed to quercetin at a concentration of $100 \mu \mathrm{mol} / \mathrm{l}$ for $72 \mathrm{~h}$ exhibited an increase of over $20 \%$ in sub- $\mathrm{G}_{0} / \mathrm{G}_{1}$ (from $2.17 \%$ in control to $24.27 \%$ ) and near $10 \%$ in $\mathrm{G}_{2} / \mathrm{M}$ fraction (from $12.77 \%$ in control to $21.18 \%$ ) accompanied by a decrease in $\mathrm{G}_{0} / \mathrm{G}_{1}$ fraction. Almost equal results were attained in Jurkat cells after treatment with 3-hydroxyflavone at the same concentration. DNA content of Jurkat cells exposed to chrysin proved a more than $42 \%$ increase in sub- $\mathrm{G}_{0} / \mathrm{G}_{1}$ fraction attendant over $38 \%$ decrease in $G_{0} / G_{1}$ fraction. This data indicates that quercetin and 3-hydroxyflavone might affect the cell cycle of Jurkat by a similar or the same mechanism of action which lead to a direct induction of apoptosis seen as an increase in sub- $G_{0} / G_{1}$ fraction and to $G_{2} / M$ arrest probably caused by an interaction with the mitotic apparatus. On the

Table 3. Flavonoids-induced apoptosis in Jurkat cells measured by flow cytometry

\begin{tabular}{lccc}
\hline & $\mathrm{An}^{-} / \mathrm{PI}^{-}$ & $\mathrm{An}^{+} / \mathrm{PI}^{-}$ & $\mathrm{An}^{+} / \mathrm{PI}^{+}$ \\
\hline Control & $96.23 \pm 2.11$ & $1.17 \pm 0.23$ & $2.41 \pm 0.10$ \\
Quercetin & $57.6 \pm 3.28^{\mathrm{a}}$ & $19.82 \pm 2.17^{\mathrm{a}}$ & $22.16 \pm 1.26^{\mathrm{a}}$ \\
Chrysin & $45.3 \pm 1.18^{\mathrm{a}}$ & $26.5 \pm 0.98^{\mathrm{a}}$ & $26.54 \pm 1.28^{\mathrm{a}}$ \\
3-Hydroxyflavone & $80.8 \pm 2.03^{\mathrm{b}}$ & $6.3 \pm 1.13^{\mathrm{c}}$ & $11.53 \pm 2.98^{\mathrm{c}}$ \\
\hline
\end{tabular}

$\mathrm{An}^{-} / \mathrm{PI}^{-}$, live cells; $\mathrm{An}^{+} / \mathrm{PI}^{-}$, early apoptic cells; $\mathrm{An}^{+} / \mathrm{PI}^{+}$, late apoptotic/necrotic cells. Cells were exposed to flavonoids $(100 \mu \mathrm{mol} / \mathrm{l})$ for 72 hours. ${ }^{\mathrm{a}} p<0.001 ;{ }^{\mathrm{b}} p<0.01 ;{ }^{\mathrm{c}} p<0.05$ vs. control. contrary, treatment of Jurkat cells with chrysin resulted only in direct induction of apoptosis in comparison to control (Tab. 2; Fig. 2).

\section{Annexin V/PI staining}

The proapoptotic effect of the examined flavones was evaluated by an annexin V/PI staining where the proportion of live, early and late apoptotic cells was detected. Exposure of Jurkat cells to chrysin eventuated into an evident increase in the proportion of early (26.5\%) and late (26.54\%) apoptotic cells. This data is in accordance with the results found in cell cycle analysis. Quercetin in comparison with 3-hydroxyflavone proved a higher proapoptotic effect recorded in the proportion of both early and late apoptotic cells. Our results suggest that 3-hydroxyflavone shows the lowest ability to induce apoptosis (Tab. 3).

\section{DNA fragmentation assay}

Analysis of DNA fragmentation by agarose gel electrophoresis is one of the most widely used biochemical markers for cell death. The detection of internucleosomal DNA cleavage (DNA laddering) is considered to be an indicator of apoptosis. In our experiment after $24 \mathrm{~h}$ of incubating Jurkat cells with quercetin and chrysin at a concentration $100 \mu \mathrm{mol} / \mathrm{l}$ DNA fragmentation was already noted and this effect also persisted after 48 and $72 \mathrm{~h}$ of incubation. DNA fragmentation induced by 3-hydroxyflavone was observed after a $48 \mathrm{~h}$ incubation which indicates a weaker proapoptotic effect than noted in the evaluation of apoptosis by annexin V/PI staining (Fig. 3).

\section{Endothelial cells migration assay}

Migration of endothelial cells in response to angiogenic factors plays an important role in angiogenesis. In this assay we studied the ability of examined flavones to inhibit endothelial cell migration observed by the overgrowth of an acellular line in the wounded areas of the confluent monolayer. All three tested flavones significantly inhibited endothelial cell migration after $24 \mathrm{~h}$ of incubation at a concentration $100 \mu \mathrm{mol} / \mathrm{l}(p<0.001)$. At a lower concentration $(10 \mu \mathrm{mol} / \mathrm{l})$ 

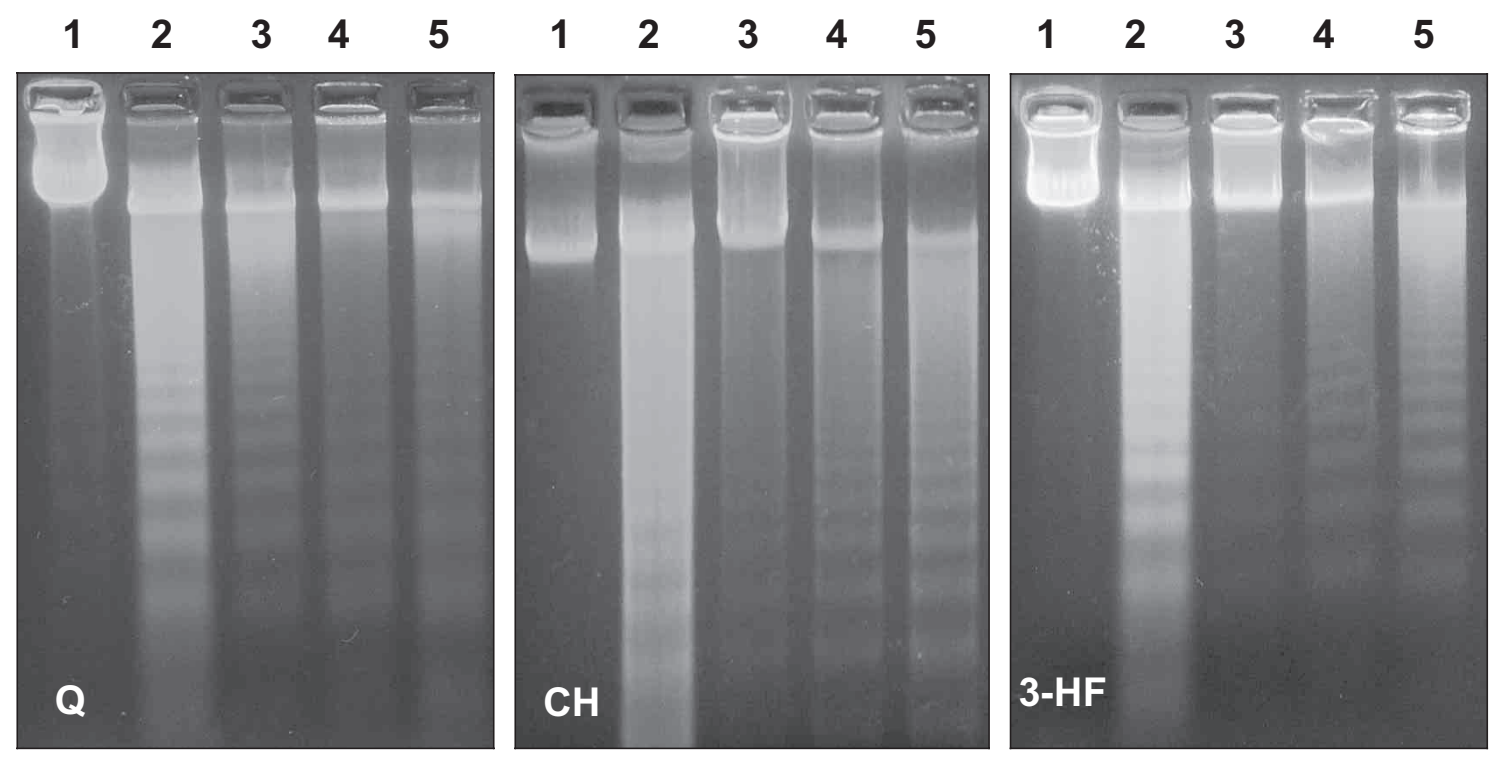

Figure 3. DNA fragmentation of Jurkat cells after 24, 48 and $72 \mathrm{~h}$ incubation with quercetin (Q), chrysin $(\mathrm{CH})$ and 3-hydroxyflavone (3-HF) at concentration $100 \mu \mathrm{mol} / \mathrm{l}$. Apoptotic DNA fragmentation was qualitatively analyzed by DNA gel electrophoresis. The extracted DNA was loaded on $2 \%$ agarose gel and was stained with ethidium bromide. Lanes indicate different treatments: 1, negative control; 2 , positive control (etoposide $50 \mu \mathrm{l} / \mathrm{ml}$ for $48 \mathrm{~h}$ ); 3, DNA fragmentation after $24 \mathrm{~h}$ of incubation with flavonoids; 4, DNA fragmentation after $48 \mathrm{~h}$ of incubation with flavonoids; 5, DNA fragmentation after $72 \mathrm{~h}$ of incubation with flavonoids.

only quercetin significantly blocked migration of endothelial cells $(p>0.05)$ (Fig. 4).

\section{In vitro angiogenesis assay}

The effect of flavonoids on formation of tubular structures of the endothelial cells was observed after a $24 \mathrm{~h}$ of incubation at a concentration $1 \mu \mathrm{mol} / \mathrm{l}$. None of compounds tested blocked microcapillary tube formation significantly (Fig. 5).

\section{MMP gelatinase activity}

To examine whether studied compounds modulate the secretion of MMP-2 and MMP-9 from HUVECs, we determined the MMP-2 and MMP-9 levels in the conditioned medium by gelatin zymography. As shown in Fig. 6, quercetin treatment decreased the secretion of MMP-2 and MMP-9 significantly compared with that of the untreated controls at concentration $10^{-4} \mathrm{~mol} / \mathrm{l}$. No influence on the secretion of MMP-2 and MMP-9 was observed after chrysin and 3-hydroxyflavone treatment.

The bands of the standard for MMP- 2 and MMP-9 reflect inactive as well as active form of studied enzymes. We determined only pro-enzyme of MMP-2 and MMP-9 in our samples, not active form of these enzymes. Therefore we can claim that quercetin treatment decrease the secretion of MMP-2 and MMP-9 and do not inhibit MMP activity.

\section{Discussion}

The possibility that intake of natural substances might reduce risk of cancer have attracted attention as eventual chemopreventive or chemotherapeutic agent. Many clinically successful anticancer drugs are themselves either natural products or have been developed from naturally occuring lead compounds (Pouget et al. 2001). The flavonoids are polyphenolic compounds found as integral components of the human diet. Several plants and spices containing flavonoid derivatives have found application as disease preventive and therapeutic agents in traditional medicine in Asia for thousands of years. The much lower risk of colon, prostate and breast cancer in Asians, who consume more vegetables, fruits and tea than populations in the Western countries do, raises the question of whether flavonoid components mediate the protective effects of diets rich in these foodstuffs by acting as natural chemopreventive and anticancer agents (Kandaswami et al. 2005). The antiproliferative effect of flavonoids has been documented on different cancer cell lines and tumor growth in animal models (Ma et al. 2006). Many mechanisms of action have been identified, including carcinogen inactivation, blockade of proliferation, cell cycle arrest, induction of apoptosis and differentiation, inhibition of angiogenesis, antioxidation and reversal of multidrug resistance or a combination of these mechanisms. Based on these results, flavonoids may be promising anticancer agents 


\section{A}

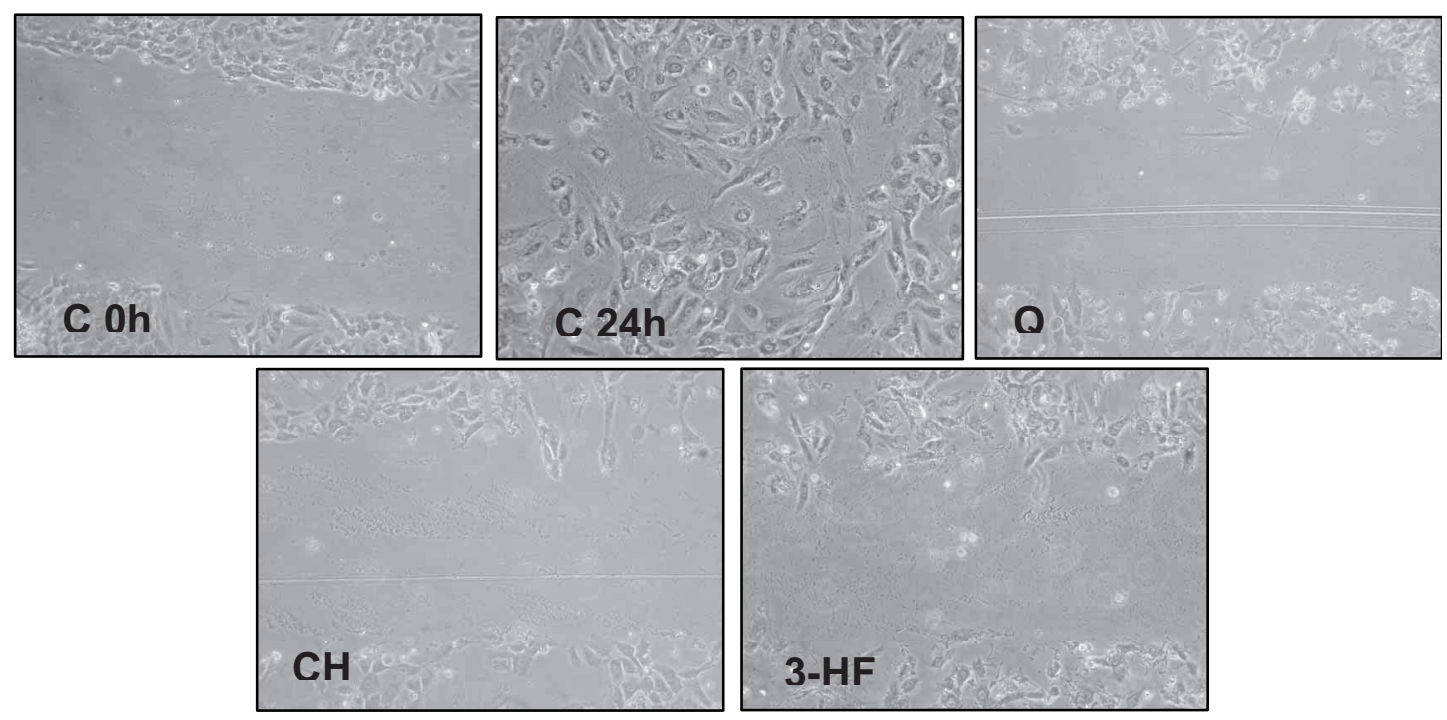

B

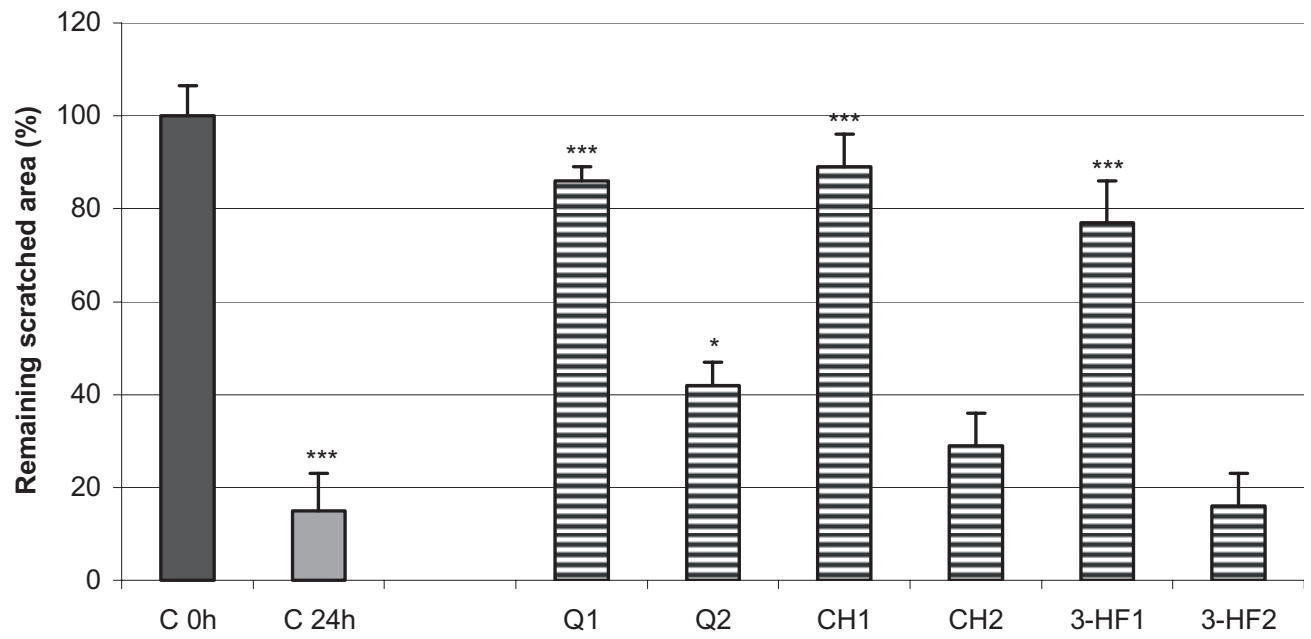

Figure 4. Inhibitory effect of quercetin $(\mathrm{Q})$, chrysin $(\mathrm{CH})$ and 3-hydroxyflavone (3-HF) on HUVECs migration in wound migration assays. Representative photographs showing the control (C Oh and C 24h) and the effect of $10^{-4} \mathrm{~mol} / \mathrm{l} \mathrm{Q}, \mathrm{CH}$ and 3-HF on HUVECs migration after $24 \mathrm{~h}$ of incubation with flavonoids (A). Percentage of remaining scratched area (B) was calculated after being marked and quantified by the histogram function of the Adobe Photoshop 5.5 program. Experiments were performed in triplicate. Compounds were tested at concentrations of $10^{-4} \mathrm{~mol} / \mathrm{l}\left(\mathrm{Q} 1, \mathrm{CH} 1\right.$ and 3-HF1) and $10^{-5} \mathrm{~mol} / \mathrm{l}\left(\mathrm{Q} 2, \mathrm{CH} 2\right.$ and 3-HF2). ${ }^{* *} p<0.001$ (C $24 \mathrm{~h} v s$. C $0 \mathrm{~h}$ and Q1, CH1 and 3-HF1 vs. C 24h); ${ }^{*} p<0.05$ (Q2 vs. C 24h).

(Ren et al. 2003). In this paper we discuss the antiproliferative and antiangiogenic effect of three flavones with different number and position of hydroxyl group and their possible mechasnisms of action.

Our results show that chrysin and 3-hydroxyflavone possess significantly higher cytotoxic effect than the reference standard quercetin on various cancer cell lines. This indicates that the higher number of hydroxyl groups is not essential for determination of antiproliferative activitity of flavones and advises of the importance of their position. Similarly, in the reports of Kawaii et al. (1999), Kuntz et al. (1999) and Yáñez et al. (2004) it has been documented stronger antiproliferative potency of flavonoids with lower number of hydroxyl groups compared with quercetin. The mechanisms by which chrysin and 3-hydroxyflavone inhibit cancer cell growth remain poorly understood. Chrysin can exert its growth-inhibitory effects through activating p38MAPK leading to the accumulation of cyclin-dependent kinase inhibitor p21 (Waf1/Cip1) or mediating the inhibition of proteasome activity (Weng et al. 2005). Inhibition of proliferation caused by down-regulated expression of PCNA after incubation with chrysin was also described (Zhang 

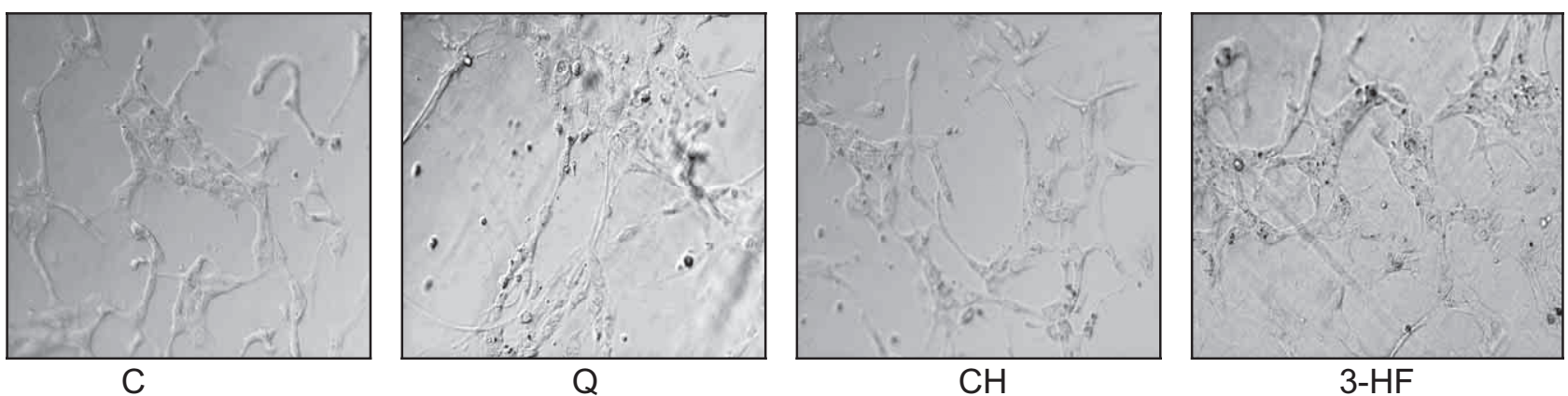

Figure 5. Effect of quercetin (Q), chrysin $(\mathrm{CH})$ and 3-hydroxyflavone (3-HF) on HUVEC tube formation on fibrin gel. Representative photomicrographs of three experiments show tube formation by HUVECs. C, control.

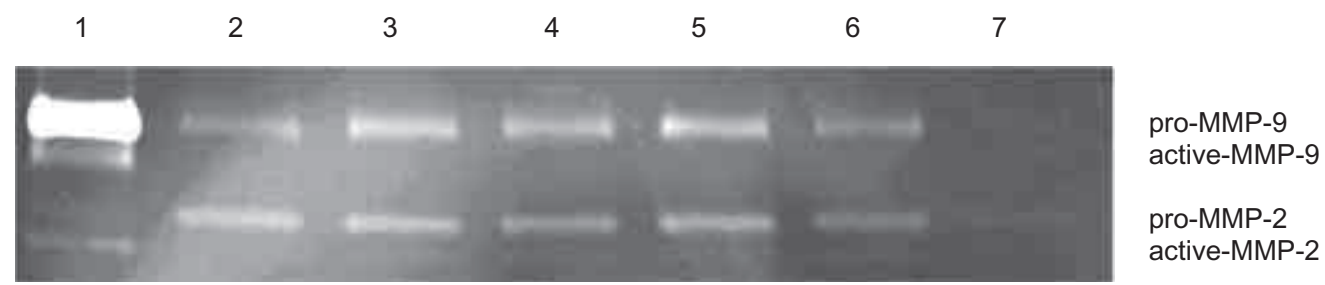

Figure 6. MMP-2 and MMP-9 protein secreted from HUVECs. Results show that quercetin downregulates secretion of MMP- 2 and MMP-9 at concentration $100 \mu \mathrm{mol} / \mathrm{l}$. Cells were incubated in the absence (lane 2) or presence (lanes 3-7) of different concentrations of quercetin, and the level of MMP-2 and MMP-9 protein secreted into the medium was measured by gelatin zymography. This is a representative gel picture of one of three separate experiments with similar results. 1, standard MMP-9 and MMP-2; 2, control; quercetin concentration (in mol/l): $10^{-8}(3), 10^{-7}(4), 10^{-6}(5), 10^{-5}(6), 10^{-4}(7)$.

et al. 2004). Proapoptotic effect of examined flavones was confirmed by cell cycle analysis with the highest response to chrysin treatmnent. DNA content of Jurkat cells exposed to chrysin showed more than $42 \%$ increase in sub- $\mathrm{G}_{0} / \mathrm{G}_{1}$ fraction attendant over $38 \%$ decrease in $G_{0} / G_{1}$ fraction. Weng et al. (2005) noted that chrysin exhibited a dose-dependent and time-dependent ability to block cell cycle progression of rat C6 glioma cell line at the $\mathrm{G}_{1}$ phase accompanied to significant increased of the expression of cyclin-dependent kinase inhibitor, p21(Waf1/Cip1) following by reduction of both cyclin-dependent kinase 2 (CDK2) and 4 (CDK4) kinase activities. This indicates that the possible mechanisms of action can vary from one cell line to another and combination of these mechanisms leads to their antiprolifertive or chemopreventive activity as the case may be, as mentioned by Ren et al. (2003). Cell cycle analysis of Jurkat cells exposed to quercetin and 3-hydroxyflavone exhibited an increase in sub- $\mathrm{G}_{0} / \mathrm{G}_{1}$ and in $\mathrm{G}_{2} / \mathrm{M}$ fraction accompanied by a decrease in $G_{0} / G_{1}$ fraction. This data indicates that quercetin and 3-hydroxyflavone might affect the cell cycle of Jurkat by a similar or the same mechanism of action which leads to a direct induction of apoptosis seen as an increase in sub$\mathrm{G}_{0} / \mathrm{G}_{1}$ fraction and to $\mathrm{G}_{2} / \mathrm{M}$ arrest probably caused by an interaction with the mitotic apparatus. The same results were achieved by Choi et al. (2001) after the incubation of the human breast carcinoma cell line MCF-7 with quercetin which induced growth inhibition through at least two different mechanisms; by inhibiting cell cycle progression through transient $\mathrm{M}$ phase accumulation and subsequent $\mathrm{G} 2$ arrest, and by inducing apoptosis. It has been shown that quercetin inhibits cancer cells proliferation by depleting cellular microtubules and perturbing cellular microtubule functions. Quercetin inhibited polymerization of microtubules and depolymerized microtubules made from purified tubulin in vitro. This flavonoid bound to tubulin at a single site and it specifically inhibited colchicine binding to tubulin. In addition, quercetin perturbed the secondary structure of tubulin. This data demonstrates that the binding of quercetin to tubulin induces conformational changes in tubulin and a mechanism through which quercetin could perturb microtubule polymerization dynamics (Gupta and Panda 2002). Detection of apoptosis was confirmed by annexin V/PI staining and DNA fragmentation, a biochemical hallmark of apoptosis in the majority of cells. The fragmentation of DNA into nucleosomal units is caused by an enzyme known as CAD, or caspase activated DNase. The weakest induction of apoptosis was caused by 3-hydroxyflavone determinated by both methods. 
Angiogenesis plays crucial role in the growth and metastasis of tumors. In the present study, we investigated effects of examined flavones on several steps of angiogenesis including proliferation, MMP-2 and MMP-9 degradation, migration and tube formation. No cytotoxic effect was noted after treatment of HUVEC cells with quercetin, but all three tested flavones inhibited endothelial cell migration after $24 \mathrm{~h}$ of incubation at a concentration $100 \mu \mathrm{mol} / \mathrm{l}$. On the other hand, none of flavonoids studied caused inhibition of microcapillary tube formation. Metastatic cancer cells and endothelial cells secrete large amounts of MMPs. Matrix metalloproteinases have been identified as agents that degrade the extracellular matrix and basement membrane, which allows their spread to distal organs. Increased activity of MMPs is associated with a number of cancers. There is a compelling evidence to suggest that MMP-2 and MMP-9 play important roles in tumor invasion and metastasis. The design of new drugs to inhibit MMP activity is, therefore, a priority. It was noted that quercetin showed significant antiangiogenic activity caused by decrease in the MMP-2 expression and activity, which is involved in the agiogenic process of migration, invasion, and tube formation (Morrow et al. 2001; Tan et al. 2003). Kim (2003) presents 3-hydroxyflavone as inhibitor in vitro angiogenesis, in part via preventing VEGF/bFGF-induced MMP-1 and uPA expression and the activation of pro-MMP-2, and via modulating activity of tissue inhibitor of metalloproteinases (TIMP-1 and TIMP-2), and plasminogen activator inhibitor (PAI-1) in HUVEC cells. Our data has shown decreased secretion of MMP-2 and MMP-9 only after incubation with quercetin at concentration $100 \mu \mathrm{mol} / \mathrm{l}$. No inhibition of secretion of MMPs after chrysin and 3-hydroxyflavone treatment was noted.

Taken together, this study indicates that flavonoids studied inhibit the proliferation of malignant cells with the involvement of apoptosis. Furthermore, among flavonoids studied, quercetin is able to interfere with some steps of angiogenesis. However, further studies are necessary to investigate the mechanism of action and to find out the relationship between the structure, character and position of substituents of natural substances and their biological activities.

Acknowledgment. This work was supported by the Slovak Research and Development Agency under the contract No. APVV0325-07 and by the Slovak Grant Agency for Science (grant No. 1/4236/07).

\section{References}

Alía M., Mateos R., Ramos S., Lecumberri E., Bravo L., Goya L. (2006): Influence of quercetin and rutin on growth and antioxidant defense system of a human hepatoma cell line (HepG2). Eur. J. Nutr. 45, 19-28; doi:10.1007/s00394005-0558-7
Cipák L., Rauko P., Miadoková E., Cipáková I., Novotný L. (2003): Effects of flavonoids on cisplatin-induced apoptosis of HL-60 and L1210 leukemia cells. Leuk. Res. 27, 65-72; doi:10.1016/S0145-2126(02)00063-2

Chan M. M., Fong D., Soprano K. J., Holmes W. F., Heverling H. (2003): Inhibition of growth and sensitization to cisplatinmediated killing of ovarian cancer cells by polyphenolic chemopreventive agents. J. Cell. Physiol. 194, 63-70; doi:10.1002/jcp.10186

Choi J. A., Kim J. Y., Lee J. Y., Kang C. M., Kwon H. J., Yoo Y. D., Kim T. W., Lee Y. S., Lee S. J. (2001): Induction of cell cycle arrest and apoptosis in human breast cancer cells by quercetin. Int. J. Oncol. 19, 837-844

Delgado M. E., Haza A. I., Arranz N., García A., Morales P. (2008): Dietary polyphenols protect against $\mathrm{N}$-nitrosamines and benzo(a)pyrene-induced DNA damage (strand breaks and oxidized purines/pyrimidines) in HepG2 human hepatoma cells. Eur. J. Nutr. 47, 479-490; doi:10.1007/ s00394-008-0751-6

Duthie G. G., Gardner P. T., Kyle J. A. M. (2003): Plant polyphenols: are they the new magic bullet? Proc. Nutr. Soc. 62, 599-603; doi:10.1079/PNS2003275

Gupta K., Panda D. (2002): Perturbation of microtubule polymerization by quercetin through tubulin binding: a novel mechanism of its antiproliferative activity. Biochemistry 41, 13029-13038; doi:10.1021/bi025952r

Hakimuddin F., Tiwari K., Paliyath G., Meckling K. (2008): Grape and wine polyphenols down-regulate the expression of signal transduction genes and inhibit the growth of estrogen receptor-negative MDA-MB231 tumors in nu/nu mouse xenografts. Nutr. Res. 28, 702-713; doi:10.1016/ j.nutres.2008.06.009

Jaffe E. A., Nachman R. L., Becker C. G., Ninick C. R. (1973): Culture of human endothelial cells derived from umbilical veins. Identification by morphologic and immunolologic criteria. J. Clin. Invest. 11, 2745-2756; doi:10.1172/JCI107470

Kandaswami C., Lee L. T., Lee P. P., Hwang J. J., Ke F. C., Huang Y. T., Lee M.T. (2005): The antitumor activities of flavonoids. In Vivo 19, 895-909

Kawaii S., Tomono Y., Katase E., Ogawa K., Yano M. (1999): Antiproliferative activity of flavonoids on several cancer cell lines. Biosci. Biotechnol. Biochem. 6, 896-899; doi:10.1271/bbb.63.896

Kim M. H. (2003): Flavonoids inhibit VEGF/bFGF-induced angiogenesis in vitro by inhibiting the matrix-degrading proteases. J. Cell. Biochem. 89, 529-538; doi:10.1002/ jcb. 10543

Kravtsov V. D., Greer J. P., Whitlock J. A., Koury M. J. (1998): Use of the microculture kinetic assay of apoptosis to determine chemosensitivities of leukemias. Blood 92, 968-980

Kuntz S., Wenzel U., Daniel H. (1999): Comparative analysis of the effects of flavonoids on proliferation, cytotoxicity, and apoptosis in human colon cancer cell lines. Eur. J. Nutr. 38, 133-142; doi:10.1007/s003940050054

Lamson D. W., Brignall M. S. (2000): Antioxidants and cancer, part 3: quercetin. Altern. Med. Rev. 5, 196-208 
Li W. X., Cui C. B., Cai B., Wang H. Y., Yao X. S. (2005): Flavonoids from Vitex trifolia L. inhibit cell cycle progression at G2/M phase and induce apoptosis in mammalian cancer cells. J. Asian Nat. Prod. Res. 7, 615-626; doi:10.1080/ 10286020310001625085

Ma L., Feugang J. M., Konarski P., Wang J., Lu J., Fu S., Ma B., Tian B., Zou C., Wang Z. (2006): Growth inhibitory effects of quercetin on bladder cancer cell. Front. Biosci. 11, 2275-2285; doi:10.2741/1970

Marin V., Kaplanski G., Gres S., Farnarier C., Bongrand P. (2001): Endothelial cell culture: protocol to obtain and cultivate human umbilical endothelial cells. J. Immunol. Methods 254, 183-190; doi:10.1016/S0022-1759(01)00408-2

Martínez C., Yàñez J., Vicente V., Alcaraz M., Benavente-García O., Castillo J., Lorente J., Lozano J. A. (2003): Effects of several polyhydroxylated flavonoids on the growth of B16F10 melanoma and Melan-a melanocyte cell lines: influence of the sequential oxidation state of the flavonoid skeleton. Melanoma Res. 13,3-9; doi:10.1097/00008390200302000-00002

Martínez-Poveda B., Quesada A. R., Medina M. A. (2005): Hypericin in the dark inhibits key steps of angiogenesis in vitro. Eur. J. Pharmacol. 516, 97-103; doi:10.1016/j.ejphar.2005.03.047

Mojzis J., Varinska L., Mojzisova G., Kostova I, Mirossay L. (2008): Antiangogenic effect of flavonoids and chalcones. Pharmacol. Res. 57, 259-265; doi:10.1016/j.phrs.2008.02.005

Mojzisova G., Mojzis J. (2008): Flavonoids and their potential health benefits: relation to heart diseases and Ccncer. In: Recent Progress in Medicinal Plant. (Vol. 21). Phytopharmacology and Therapeutic Values III. (Eds. Singh V. K and Govil J. N.), pp. 105-129, Studium Pres LLC, Houston, Texas, USA

Mojzisova G., Kuchta M. (2001): Dietary flavonoids and risk of coronary heart disease. Physiol. Res. 50, 529-535

Morrow D. M., Fitzsimmons P. E., Chopra M., McGlynn H. (2001): Dietary supplementation with the anti-tumour promoter quercetin: its effects on matrix metalloproteinase gene regulation. Mutat. Res. 480-481, 269-276; doi:10.1016/ S0027-5107(01)00184-1

Mosmann T. (1983): Rapid colorimetric assay for cellular growth and survival: application to proliferation and cytotoxicity assays. J. Immunol. Methods 65, 55-63; doi:10.1016/00221759(83)90303-4
Newcomb E. W., Ali M. A., Schnee T., Lan L., Lukyanov Y., Fowkes M., Miller D. C., Zagzag D. (2005): Flavopiridol downregulates hypoxia-mediated hypoxia-inducible factor-1alpha expression in human glioma cells by a proteasome-independent pathway: implications for in vivo therapy. Neuro Oncol. 7, 225-235; doi:10.1215/S1152851704000997

Pouget C., Lauthier F., Simon A., Fagnere C., Basly J. P., CDelage C. Chulia A. J. (2001): Flavonoids: structural requirements for antiproliferative activity on breast cancer cells. Bioorg. Med. Chem. Lett. 11, 3095-3097; doi:10.1016/S0960894X(01)00617-5

Ren W., Qiao Z., Wang H., Zhu L., Zhang L. (2003): Flavonoids: promising anticancer agents. Med. Res. Rev. 23, 519-534; doi:10.1002/med.10033

Sivoňová M., Žitňanová I., Horáková L., Štrosová M., Muchová J., Balgavý P., Dobrota D., Ďuračková Z. (2006): The combined effect of pycnogenol with ascorbic acid and trolox on the oxidation of lipids and proteins. Gen. Physiol. Biophys. 25, 379-396

Tan W. F., Lin L. P., Li M. H., Zhang Y. X., Tong Y. G., Xiao D., Ding J. (2003): Quercetin, a dietary-derived flavonoid, possesses antiangiogenic potential. Eur. J. Pharmacol. 459, 255-262; doi:10.1016/S0014-2999(02)02848-0

van Rijn J., van den Berg J. (1997): Flavonoids as enhancers of Xray-induced cell damage in hepatoma cells. Clin. Cancer Res. 3, 1775-1779

Weng M. S., Ho Y. S., Lin J.K. (2005): Chrysin induces G1 phase cell cycle arrest in C6 glioma cells through inducing p21Waf1/ Cip1 expression: involvement of p38 mitogen-activated protein kinase. Biochem. Pharmacol. 69, 1815-1827; doi:10.1016/j.bcp.2005.03.011

Yáñez J., Vicente V., Alcaraz M., Castillo J., Benavente-García O., Canteras M., Teruel J. A. (2004): Cytotoxicity and antiproliferative activities of several phenolic compounds against three melanocytes cell lines: relationship between structure and activity. Nutr. Cancer 49, 191-199; doi:10.1207/ s15327914nc4902_11

Zhang T., Chen X., Qu L., Wu J., Cui R., Zhao Y. (2004): Chrysin and its phosphate ester inhibit cell proliferation and induce apoptosis in Hela cells. Bioorg. Med. Chem. 12, 6097-6105; doi:10.1016/j.bmc.2004.09.013

Received: July 6, 2009

Final version accepted: January 15, 2010 